\title{
OSTEOPOROSIS AS A NOVEL MARKER OF UTERINE CANCER RISK FACTOR
}

\author{
Zena Abdul Monim Al-Jawadi and Zainab Mahfoth Al-noaymy \\ Department of Chemistry, College of Science, University of Mosul, Mosul, Iraq
}

Received 2013-09-20; Revised 2013-10-18; Accepted 2013-12-07

\begin{abstract}
Due to limited available information on the occurrence and treatment of uterine cancer, health institutions in major countries trend to study some factors and diseases that may relation or plays as predisposing factors of the occurrence of uterine cancer and the lack of previous studies on the impact of osteoporosis on the incidence of uterine cancer and the rapid spread of uterine cancer in recent years all over the world and till know the exact mechanism is not fully clear. This study focused on the following: Possibility of osteoporosis as a marker of uterine cancer by studying the relationship between osteoporosis and uterine cancer through a biochemical and hormonal parameters responsible for osteoporosis and its effect on uterus and possibility of malignant changes. The study included collection of samples attending the Hospitals in Mosul, from 82 women had no uterine cancer and divided to two groups (44 healthy women and 38 women diagnosed as osteoporosis only) and 101 women with uterine cancer (43 with uterine cancer only and 58 women are associated osteoporosis with uterine cancer dose not received any treatment for their condition). Each patient was evaluated clinically and by a biochemical laboratory tests, which include phosphorus, calcium, vitamin $\mathrm{D}_{3}$, alkaline phosphatase ALP, estrogen and progesterone in serum by using commercial kits. The results showed the osteoporosis may increases the incidence of uterine cancer. Novel of this research showed that Osteoporosis is a new risk factor for uterine cancer. Accordingly, women should pay attention for her bone health and early diagnosis and treatment of osteoporosis to prevent and reduce the risk of uterine cancer.
\end{abstract}

Keywords: Osteoporosis, Vitamin D, Estrogen, Progesterone, ALP

\section{INTRODUCTION}

Uterine cancer is the third most common malignant tumors in women and the incidence of uterine cancer has doubled over the last six years. Where more than $40 \%$ of malignant tumors in women is a cancer of the uterus. It is the third most common cancer in females after breast and ovarian cancer and carry a high death rate (Yang et al., 2011). Although a large number of women affected, the pathophysiological mechanisms is still largely unknown (Haughian et al., 2009).

Osteoporosis is common in older people and in postmenopausal women. It is a growing health problem worldwide and women in pre-menopausal stage are at high risk the disease after the next twenty years. The major determinant of bone strength and the risk of osteoporosis is Bone Mineral Density (BMD), which increases the chance of fractures is due to lack of the hormone estrogen, which helps to integrate calcium in the bones, in addition to mineral deficiency responsible for bone density (Kamienski et al., 2011). To build strong bones it needs calcium, phosphorus and vitamin D (Lips and Schoor, 2011; Trummer et al., 2012). Vitamin $\mathrm{D}$ may play a protective role in human cancer. There is need for further studies to verify that the protective effect of calcium and vitamin $\mathrm{D}$ can be expanded to uterine cancer (Byers, 2010). The aim of this study is the possibility of osteoporosis as a marker of uterine cancer

Corresponding Author: Zena Abdul Monim Al-Jawadi, Department of Chemistry, College of Science, Mosul University, Mosul, Iraq 
by studying the relationship between osteoporosis and uterine cancer through a biochemical and hormonal parameters responsible for osteoporosis and its effect on uterus and possibility of malignant changes and this is done for the first time.

\section{MATERIALS AND METHODS}

The study included collection of samples attending the Hospitals in Mosul, from 82 women had no uterine cancer and divided to two groups (44 healthy women and 38 women diagnosed as osteoporosis only) and 101 women with uterine cancer (43 with uterine cancer only and 58 women are associated osteoporosis with uterine cancer dose not received any treatment for their condition). Each patient was evaluated clinically and by a biochemical laboratory tests, which include estrogen, progesterone, vitamin $\mathrm{D}_{3}$, calcium, phosphorus and alkaline phosphatase ALP in serum by using commercial kits (Bio Merieux Vitek, Inc., UAS).
The statistical methods used to analysis the data include mean, standard deviation, minimum and maximum, while T-test was used to compare between total control and total patients according to the occupation at $\mathrm{p} \leq 0.05$ and $\mathrm{p} \leq 0.001$ (Kirkpatrick and Feeney, 2012).

\section{RESULTS}

The result in Table 1 showed a significant differs at $p$ $=0.001$ of biochemical parameters (Vit. $\mathrm{D}_{3}$ and $\mathrm{P}$ ) on women uterine cancer compared with control group.

Result in Table 2 showed a significant differs at $\mathrm{p}=$ $0.05, p=0.04, p=0.04, p=0.03$ and $p<0.0001$ of biochemical parameters (Estrogen, Progesterone, Vit. $\mathrm{D}_{3}$, $\mathrm{P}$ and ALP) on women with uterine cancer compared with women osteoporosis group.

Table 3 showed a significant differs at $\mathrm{p}<0.0001, \mathrm{p}=$ 0.05 and $p<0.001$ and $p \leq 0.0001$ of biochemical parameters (Vit. $\mathrm{D}_{3}, \mathrm{Ca}$ and ALP) on women with osteoporosis and uterine cancer compared with control group.

Table 1. Effect of biochemical parameters on women with uterine cancer and control group

\begin{tabular}{lccc}
\hline Biochemical & Woman with Uterine & Control group & \\
Parameters & Cancer Mean \pm S.E & Mean \pm S.E & P values \\
\hline Estrogen $(\mathrm{pg} / \mathrm{mL})$ & $48.04 \pm 17.2$ & $38.65 \pm 16.4$ & $\mathrm{~N}$ \\
Progesterone $(\mathrm{ng} / \mathrm{mL})$ & $0.75 \pm 0.3$ & $1.25 \pm 0.12$ & $\mathrm{~N}$ \\
Vit. $\mathrm{D}_{3}(\mu \mathrm{g} / \mathrm{L})$ & $29.59 \pm 6.6$ & $38.24 \pm 14.74 * * *$ & 0.001 \\
Calcium $(\mathrm{mmol} / \mathrm{L})$ & $1.27 \pm 0.29$ & $1.46 \pm 0.21^{* * *}$ & 0.001 \\
ALP $(\mathrm{U} / \mathrm{L})$ & $67.51 \pm 10.45$ & $71.09 \pm 12.5$ & $\mathrm{~N}$ \\
\hline
\end{tabular}

***; Significant differences at $\mathrm{p}=0.001$

Table 2. Effect of biochemical parameters on women with uterine cancer and osteoporosis compared with control group

\begin{tabular}{lccc}
\hline $\begin{array}{l}\text { Biochemical } \\
\text { parameters }\end{array}$ & $\begin{array}{l}\text { Woman with uterine } \\
\text { cancer mean } \pm \text { S.E }\end{array}$ & Woman with & \\
\hline Estrogen $(\mathrm{pg} / \mathrm{mL})$ & $48.04 \pm 17.2$ & $91.01 \pm 10.3^{*}$ & P values \\
Progesterone $(\mathrm{ng} / \mathrm{mL})$ & $0.75 \pm 0.3$ & $2.41 \pm 0.5^{*}$ & 0.05 \\
Vit. $D_{3}(\mu \mathrm{g} / \mathrm{L})$ & $29.59 \pm 6.6$ & $26.6 \pm 6.02^{*}$ & 0.04 \\
Calcium $(\mathrm{mmol} / \mathrm{L})$ & $2.36 \pm 0.16$ & $2.39 \pm 0.19$ & 0.04 \\
phosphorus $(\mathrm{mmol} / \mathrm{L})$ & $1.27 \pm 0.29$ & $1.39 \pm 0.15^{*}$ & $\mathrm{~N}$ \\
ALP $(\mathrm{U} / \mathrm{L})$ & $67.51 \pm 10.45$ & $95.79 \pm 21.2^{* * *}$ & 0.03 \\
\hline
\end{tabular}

*; Significant differences at $\mathrm{p} \leq 0.05, * * * ;$ Significant differences at $\mathrm{p} \leq 0.001$

Table 3. Effect of biochemical parameters on women with Osteoporosis and uterine cancer compared with control group

\begin{tabular}{lccc}
\hline Biochemical & Osteoporosis and uterine & Control group & \\
Parameters & cancer Mean \pm S.E & Mean \pm S.E & P values \\
\hline Estrogen $(\mathrm{pg} / \mathrm{mL})$ & $24.41 \pm 17.2$ & $38.65 \pm 16.4$ & $\mathrm{~N}$ \\
Progesterone $(\mathrm{ng} / \mathrm{mL})$ & $0.92 \pm 0.2$ & $1.25 \pm 0.12$ & $\mathrm{~N}$ \\
Vit. $\mathrm{D}_{3}(\mu \mathrm{g} / \mathrm{L})$ & $21.88 \pm 11.5$ & $38.24 \pm 14.74 * * *$ & $<0.0001$ \\
Calcium $(\mathrm{mmol} / \mathrm{L})$ & $2.4 \pm 0.26$ & $2.32 \pm 0.14 *$ & 0.05 \\
phosphorus $(\mathrm{mmol} / \mathrm{L})$ & $1.45 \pm 0.55$ & $1.46 \pm 0.21$ & $\mathrm{~N}$ \\
ALP $(\mathrm{U} / \mathrm{L})$ & $113.34 \pm 52.08$ & $71.09 \pm 12.5 * * *$ & $<0.001$ \\
\hline
\end{tabular}

*; Significant differences at $\mathrm{p} \leq 0.05, * * *$ Significant differences at $\mathrm{p} \leq 0.001$ 
Table 4. Effect of biochemical parameters on women with Osteoporosis and uterine cancer compared with osteoporosis group

\begin{tabular}{lccc}
\hline Biochemical & Osteoporosis and uterine & Woman with & \\
Parameters & cancer Mean \pm S.E & Osteoporosis Mean \pm S.E & P values \\
\hline Estrogen $(\mathrm{pg} / \mathrm{mL})$ & $24.41 \pm 17.2$ & $91.01 \pm 10.3^{* * *}$ & $<0.0001$ \\
Progesterone $(\mathrm{ng} / \mathrm{mL})$ & $0.92 \pm 0.2$ & $2.41 \pm 0.5^{*}$ & 0.02 \\
Vit. $D_{3}(\mu \mathrm{g} / \mathrm{L})$ & $21.88 \pm 11.5$ & $26.6 \pm 6.02^{*}$ & 0.02 \\
Calcium $(\mathrm{mmol} / \mathrm{L})$ & $2.4 \pm 0.26$ & $2.39 \pm 0.19$ & $\mathrm{~N}$ \\
Phosphorus $(\mathrm{mmol} / \mathrm{L})$ & $1.45 \pm 0.55$ & $1.39 \pm 0.15$ & $\mathrm{~N}$ \\
ALP $(\mathrm{U} / \mathrm{L})$ & $113.34 \pm 52.08$ & $95.79 \pm 21.2^{*}$ & 0.05 \\
\hline
\end{tabular}

*; Significant differences at $\mathrm{p} \leq 0.05, * * *$ Significant differences at $\mathrm{p} \leq 0.001$

Result in Table 4 showed a significant differs at $p<0.0001, p=0.02$ and $p=0.02$ and $p=0.05$ of biochemical parameters (Estrogen, Progesterone, Vit. $\mathrm{D}_{3}$ and ALP) on women with Osteoporosis and uterine cancer compared with women osteoporosis group.

\section{DISCUSSION}

Uterine cancer is very common in female and like most malignant tumors there is no apparent reason for its occurrence but it is certain that hormones plays important factor affecting this organ. Through the relationship between imbalance female hormones, especially estrogen effect on bone density lead to osteoporosis and its one of the risk factors for uterine cancer as seen in Table 2 and 4. The exoskeleton of the body and therefore they need maintenance a permanent support where they are rebuilt continuously through the stages of life, the bone cells begin construction and reach a peak in the age of twenty, but after the third and fourth decade over widening between bone cells and be the loss is more than building at the proximity of the fifth decade, the loss rate up to more than $25 \%$ of the skeleton. Osteoporosis is a silent disease, where bone density gradually. The study showed that low serum levels of vitamin $\mathrm{D}_{3}$ as seen in Table 2, have effect on osteoporosis and this consistent with other study (Watts et al., 2012). As well as lower serum vitamin $\mathrm{D}_{3}$ in women with osteoporosis and uterine cancer, as shown in Table 3 and 4, probably for the same reason. It is well known that vitamin $D_{3}$ regulate the level of phosphorus and calcium in the blood by participating in the process of mineral metabolism and bone growth and this was confirmed by the results in (Table 1-3). In the absence of vitamin $\mathrm{D}_{3}$, calcium and phosphorus does not absorbed with high efficiency (Calvo and Uribarri, 2013; Yousef et al., 2013) and thus withdrawn from the bones into the blood and this may not seen clearly in the blood and this is what shown in the (Table 1-4) and as a result increase the level of the enzyme alkaline phosphatase which is one of the most important clinical biochemical indicators of osteoporosis (Gonzlez-Perez et al., 2011). This study showed that osteoporosis may increases the incidence of uterine cancer. Accordingly, women should pay attention for her bone health and early diagnosis and treatment of osteoporosis to prevent and reduce the risk of uterine cancer.

\section{CONCLUSION}

Novel of this research showed that Osteoporosis is a new risk factor for uterine cancer. Accordingly, women should pay attention for her bone health and early diagnosis and treatment of osteoporosis to prevent and reduce the risk of uterine cancer.

\section{REFERENCES}

Byers, T., 2010. Anticancer Vitamins du jour-the ABCED's so far. Am. J. Epidemiol., 172: 1-3. DOI: 10.1093/aje/kwq112

Calvo, M.S. and J. Uribarri, 2013. Public health impact of dietary phosphorus excess on bone and cardiovascular health in the general population. Am. J. Clin. Nutr., 98: 15-16. DOI: 10.3945/ajen.112.053934

Gonzlez-Perez, J.M., E. Gonzalez-Reimers, M.C. DuranCastelln, F. Santolaria-Fernandez and L. GalindoMartn et al., 2011. Relative and combined effects of selenium, protein deficiency and ethanol on bone. J. Trace Elements Med. Biol., 25: 113-117. DOI: 10.1016/j.jtemb.2011.01.002

Haughian, J.M., R.M. Elaine, A.M. Thorne and A.P. Bradford, 2009. Protein Kinase C alpha (PKCa) dependent signaling mediates endometrial cancer cell growth and tumorigenesis. Int. J. Cancer, 125: 2556-2564. DOI: 10.1002/ijc. 24633

Kamienski, M., D. Tate and M. Vega, 2011. The silent thief: Diagnosis and management of osteoporosis. Orthop. Nurs., 30: 162-171. PMID: 21597343 
Kirkpatrick, L. and B.C. Feeney, 2012. A Simple Guide to IBM SPSS Statistics for Versions 18.0 and 19.0. 11th Edn., Wadsworth Cengage Learning, Belmont, ISBN10: 1111352550 , pp: 115.

Lips, P. and N.M. Schoor, 2011. The effect of vitamin D on bone and osteoporosis. Best Pract. Res. Clin. Endocrinol. Metabol., 25: 585-591. PMID: 21872800

Trummer, O., V. Schwetz, D. Walter-Finell, E. Lerchbaum and W. Renner et al., 2012. Allelic determinants of vitamin D insufficiency, bone mineral density and bone fractures. J. Clin. Endocrinol. Metab., 97: E1234-E1240. DOI: 10.1210/jc.2011-3088
Watts, N.B., R.A. Adler, J.P. Bilezikian, M.T. Drake and R. Eastell et al., 2012. Osteoporosis in men: An endocrine society clinical practice guideline. J. Clin. Endocrinol. Metab., 97: 1802-1822. DOI: 10.1210/jc. 2011-3045

Yang, S.H., K.T. Thiel and K.L. Leslie, 2011. Metabolism: Progesterone the ultimate endometrial tumor suppressor. Trends Endocrinol. Metab., 22: 145-152. DOI: 10.1016/j.tem.2011.01.005

Yousef, F.M., E.T. Jacobs, P.T. Kang, I.A. Hakim and S. Going et al., 2013. Vitamin D status and breast cancer in Saudi Arabian women: Case-control study. Am. J. Clin. Nutr., 98: 105-110. DOI: 10.3945/ajen.112.054445 